\title{
THE EUROPEAN INTERNAL MARKET AND THE COMPETITION BETWEEN WORKERS
}

\author{
Herwig Verschueren ${ }^{*}$
}

\begin{abstract}
This article examines to what extent European internal market law has led to regulatory competition between Member States in the field of labour law. Such competition is not limited to the relations between the Member States. Regulatory competition can also occur within the territory of the same Member State, since the internal market also influences the definition of the territorial scope of national labour law, in particular when a cross-border aspect is involved. This article looks into these questions from a legal point of view. First it summarises the principle underlying these issues, more specifically the fact that labour law continues, in the first place, to be a matter of national competence. It subsequently analyses the impact of, and the interplay between, the freedom of movement for workers, the freedom to provide services and the rules of private international law. It pays special attention to the meaning of Posting of Workers Directive 96/71 and analyses how this Directive and the case law of the Court of Justice relating to it are situated at the cross-roads of legal rules and economic interests.
\end{abstract}

Keywords: EU internal market; freedom of movement for workers; free provision of services; posting of workers; private international law; regulatory competition

\section{INTRODUCTION}

The European Union distinguishes itself in the first place by its internal market which guarantees the free movement of goods, services, capital and labour (Articles 26-66 TFEU). The possibilities offered by the internal market to deliver goods and services in other Member States have an influence on the pay and working conditions of employees in the various Member States. Indeed, these pay and working conditions

Professor of International and European Social Law at the University of Antwerp. Visiting professor at the Vrije Universiteit Brussels. This article is based on a Dutch version that was published earlier in Sociaal Economische Wetgeving (SEW) 2014, 550-564. 
are an important part of the cost price of goods and services. Consequently, through the competition between producers and suppliers of goods and services the pay and working conditions under which these goods and services are delivered can be put under pressure. Given that in the absence of a thorough harmonisation at the European level, employment protection remains, to a large extent, a matter for the Member States, this pressure not only leads to a form of competition of social norms between the Member States but also to competition between workers who are subject to different levels of employment protection.

This competition is not limited to the relations between the Member States. The European internal market also makes it possible for employees to go and work in other Member States or to be posted there by their employers. That way regulatory competition can also occur within the territory of the same Member State. Indeed, the internal market also influences the definition of the territorial scope of national labour law, in particular when a cross-border aspect is involved. Moreover, the growing occurrence of cross-border elements is an unavoidable consequence of the growing European market integration. As a result there can be circumstances in which work carried out on the territory of a certain Member State is not necessarily subject to that Member State's labour law. These restrictions on the application of the host Member State's labour legislation in its own territory undeniably pressurises the protection level of this Member State. In the same vein, it offers employers from sending Member States the possibility to take competitive advantage of the differences in employment protection and its costs.

This article looks into the question of the extent to which European internal market law has resulted in this kind of competition in social norms between Member States, and the extent to which it has influenced the territorial application of labour law. First we refer to the origins of the principle that labour law continues to be a matter of national competence (2) and comment on the regulatory competition between Member States in the field of pay and employment protection (3). Subsequently we examine the European rules and case law relevant for the definition of the territorial scope of national labour law (4). This includes the law on the freedom of movement for workers, the rules of private international law (PIL) as well as the Court of Justice (CJ) case law regarding the freedom to provide of services. We pay special attention to the meaning of Posted Workers' Directive 96/71 and analyse how this Directive and the case law of the Court of Justice relating to this are at the crossroads of legal rules and economic interests. Finally, we draw some conclusions on the ensuing competition between workers in the European internal market (5).

\section{IN PRINCIPLE LABOUR LAW CONTINUES TO BE A MATTER OF NATIONAL COMPETENCE}

At the start of the European integration in the 1950s labour law was deliberately left out of the European sphere of competence. The EEC Treaty of 1957 hardly paid any 
attention to social law and social policy in general. The focus was on the establishment of a common European market with the four freedoms (goods, persons, services and capital) and competition policy as the corner stone. The idea was that the increase of productivity as a result of the creation of a common market would automatically lead to the improvement of the living and working conditions and that therefore the EEC only had to be awarded few, if any, powers in terms of social law. ${ }^{1}$ This starting point also complied with the Member States' wish to decide for themselves how to deal with social matters with due attention to the characteristics of their own social and political structures.

This is called 'embedded liberalism'2: freeing the market was considered to be the responsibility of the international and/or supranational level, yet this free market was embedded in social policy and social law schemes that were to remain the exclusive right of the national states. The Member States retained the authority to compensate for possible negative effects of the internal market through their social legislation. This is one of the elements as a result of which the creation of the European internal market was legitimised. Incidentally, it was expected that through the functioning of the common market the Member States would be able to boost their social protection. ${ }^{3}$

Now, more than 50 years later we know that it did not exactly go that way. This is not the place to analyse the manner in which the relationship between the internal market and social law has evolved at political and legal levels. ${ }^{4}$ However, summarising, we could say that the economic integration of the Member States through the internal market most certainly has had an impact on practically all fields of the legislation and policy of the Member States, and that territorially and nationally conceived social law has not escaped this influence. Through the so-called 'negative integration', which, among other things, aimed at the removal of obstacles to the free movement of persons and services, social legislation came under pressure. This social legislation was regarded by the Court of Justice (CJ) as a possible obstacle to this free movement. ${ }^{5}$ The European institutions, and especially the Court of Justice, have

$1 \quad$ See in particular Article 117 EEC Treaty.

2 S. Guibboni, Social Rights and Market Freedom in the European Constitution. A Labour Law Perspective, Cambridge, Cambridge University Press, 2006, 29 et seq.

3 S. Deakin, 'The Lisbon Treaty, the Viking and Laval Judgments and the Financial Crisis: In Search of New Foundations for Europe's 'Social Market Economy', in N. Bruun, K. Lörcher and I. Schömann (eds.), The Lisbon Treaty and Social Europe, Oxford, Hart, 2012, 21-23.

4 For an extensive analysis of this history, with footnote references to the relevant literature see Guibboni, S., o.c. See also: C. Barnard, EU Employment Law, Oxford, Oxford University Press, 2012, 3-45 and B. Bercusson, European Labour Law, Cambridge, Cambridge University Press, 2009, 101125.

5 See about the relation between the European market integration and national social law a.o.: D. Ashiagbor, 'Embedding Trade Liberalization in Social Policy: Lessons from the European Union?', Comparative Labour Law and Policy Journal 2011, 373-404; C. Barnard, EU Employment Law, o.c., 35-45 en 189-251; P. Craig, The Lisbon Treaty. Law, Politics, and Treaty Reform, Oxford, Oxford University Press, 2012, 287-329; S. Deakin, 'Regulatory competition after Laval', in: C. Barnard (ed.), The Cambridge Yearbook of European Legal Studies, Vol. 10, 2007-2008, Oxford, Hart, 2008, 
been trying to find a balance between the economic market freedoms, which were granted the status of 'fundamental rights' and the employment protection in the national law of Member States. In doing so the social dimension was pushed into a subordinate and defensive role which is clearly illustrated in the much-discussed judgments by the Court of Justice in Viking and Laval. ${ }^{7}$

Despite the fact that the Member States' labour law has ended up in the economic and social context of the European internal market, the European legislature itself has only intervened to a limited extent in this matter. The small repertory of European employment rules and regulations is a result of the limited powers granted by the European treaties to the European legislature ${ }^{8}$ as well as of the absence of a political consensus to make ample use of these powers. It is still a matter of what has been described by SCHARF as the 'constitutional asymmetry' within the EU between the economic objectives and internal market law on the one hand and the social objectives and social law on the other. ${ }^{9}$ This has led, among other things, to the fact that at the European level economic objectives continue to be the dominant ones and influence and restrict the social law and social policy of Member States.

Yet, the European legislation that has been developed over the past decades should not be ignored. It is not our intention to analyse this development in depth in this contribution but we do want to state that in a number of fields this legislation has produced a far-reaching form of harmonisation, such as in the matter of the ban on discrimination, and health and safety in the workplace, and in other fields harmonisation, albeit less thorough, through minimum standards, e.g. with regard to working hours, the restructuring of undertakings and the rights of workers with a-typical employment contracts. However, as regards other essential elements of both individual and collective labour law, national law has retained its leading role. Therefore the question is whether this has given rise to indirect social competition between the Member States, a form of competition which is said to have put downward pressure on labour law protection in the Member States. ${ }^{10}$

581-609; S. Guibboni, Social Rights and Market Freedom in the European Constitution. A Labour Law Perspective, o.c., 79-81; S. Leibfried, 'Social Policy. Left to the Judges and the Markets?', in: H. Wallace e. a. (eds.), Policy-Making in the European Union, Oxford, Oxford University Press, 2010, 253-281; F. Rödl, 'The Labour Constitution', in: A. von Bogdandy and J. Bast, Principles of European Constitutional Law, Oxford, Hart, 2010, 624-657 and F. Scharf, 'The asymmetry of European integration, or why the EU cannot be a "social market economy", Socio-Economic Review, 2010, 221-223.

6 See, inter alia, Case C-55/94, Gebhard.

7 Case C-438/05, Viking and Case C-341/05, Laval.

8 However, these powers were gradually developed further, in particular by the Maastricht Treaty of 1992 and the Treaty of Amsterdam of 1996. For the present state of affairs see a.o.: K. Lörcher, 'Social Competences', in: N. Bruun, K. Lörcher and I. Schömann (eds.), The Lisbon Treaty and Social Europe, Oxford, Hart, 2012, 165-234.

9 F. Scharf, 'The European Social Model: Coping with the Challenges of Diversity', Journal of Common Market Studies, 2002, 645 et seq.

10 In this contribution we will not look into the (baleful) influence of the European monetary and budgetary policy, especially for the countries of the Euro zone, on the employment protection in 


\section{COMPETITION OF SOCIAL NORMS BETWEEN MEMBER STATES}

Right at the beginning of the European integration the authors of the Treaty of Rome were aware that the difference in employment protection between the Member States could cause a disturbance in the competition between the Member States' undertakings. This was, for instance, expressed in the provision of the then Article 119 EEC (now Article 157 TFEU) on the prohibition of discrimination on grounds of sex with regard to wages. This provision was intended to prevent unfair competition within the internal market. In Defrenne the Court of Justice expressly recognised this objective by stating that 'in the light of the different stages of the development of social legislation in the various Member States, the aim of Article 119 is to avoid a situation in which undertakings established in states which have actually implemented the principle of equal pay suffer a competitive disadvantage in intra-Community competition as compared with undertakings established in states which have not yet eliminated discrimination against women workers as regards pay. ${ }^{11} \mathrm{~A}$ similar role is played by the prohibition of discrimination on grounds of nationality with regard to migrant workers ${ }^{12}$ and by the prohibition of discrimination on other grounds that was later introduced through Directive 2000/4313 and Directive 2000/78. ${ }^{14}$ A comparable objective is also at the basis of the series of employment directives adopted by the European institutions over the past decades, such as the Directives on health and safety in the workplace. For instance, in a judgment on the Directive on the rights of workers in the case of transfer of undertaking ${ }^{15}$ there is a reference to the promotion of fair competition between undertakings within the internal market as an objective of European social legislation. According to the Court one of the objectives of this Directive is 'both to ensure comparable protection for employees' rights in the different

these Member States. See, in this respect more, in, amongst many others: E. Balamonti, 'Evaluating the new rules of EU economic governance in times of crisis', ELLJ 2014, 95-109; C. Barnard, 'The Financial Crisis and the Euro Plus Pact: A Labour Lawyer's Perspective', Industrial Law Journal 2012, 98-114; S. Bekker and S. Klosse, 'The changing legal context of employment policy coordination', ELLJ 2014, 6-17; S. Clauwaert and I. Schömann, The crisis and national labour law reforms: a mapping exercise, ETUI working paper 2012.04, Brussels, 2012, 19 p. and C. Kilpatrick and B. De Witte (eds.), Social Rights in Times of Crisis in the Eurozone: The Role of Fundamental Rights' Challenges, EUI Working papers, LAW 2014/05, San Domenico di Fiesole, 2014, 120 p (also published in European Journal of Social Law, 2014, 2-139).

11 Case 43/75, Defrenne II, paras 9 and 10. See also Case C-50/96, Schröder, paras 53 to 55.

12 See further under 4.1.

13 Directive 2000/43/EC of the Council of 29 June 2000 implementing the principle of equal treatment between persons irrespective of racial or ethnic origin, OJ L 2000/180, 22.

14 Directive 2000/78/EC of the Council of 27 November 2000 establishing a general framework for equal treatment in employment and occupation, OJ L 2000/303, 16.

15 Directive 77/187/EEC of the Council of 14 February 1977 on the approximation of the laws of the Member States relating to the safeguarding of employees' rights in the event of transfers of undertakings, businesses or parts of businesses, OJ L 1977/61, 26. 
Member States and to harmonize the costs which those protective rules entail for Community undertakings'. ${ }^{16}$

This goes to show that apparently European labour legislation has a double objective: market adjustment as well as market promotion. As for the latter, European employment law wants to create a 'level playing field' of social rights in order to avoid disruption of the competition between the undertakings of the various Member States. ${ }^{17}$ Yet, as the result is nothing but a very fragmentary form of European labour law one can hardly refer to European labour law as an entity.

So in principle, the differences between the Member States, both in terms of the structure of labour law and in terms of the level of the workers' rights and protection, are maintained. In the present European Union with its 28 Member States these differences are even bigger than during the development of the European internal market in the 1960s. This means that within the European internal market it is still possible for Member States to try to give their undertakings competitive advantages by cheapening the employment protection they have to offer their employees. Within the internal market this kind of competition of social norms means that for the actors in this market the differences between the legislation of the Member States could be a motive to make use of the free movement within this internal market. This is, for instance, the case when an employee from one Member State goes to work in another one because the pay and working conditions over there are better. But it also means that employers may choose to operate in a Member State with lower labour costs. This could be a boost for the economic development of the Member State concerned, but more often this is regarded as leading to a 'race to the bottom': Member States try to be more competitive by cutting back their employment protection. ${ }^{18}$

Through the difference in pay level and employment protection between the Member States the labour costs for the production of goods and services continue to vary greatly in the various Member States of the European internal market. However, it is not quite clear whether and to what extent the competition between the Member States is falsified by these differences and whether this leads to a downward spiral as regards employment protection of workers, or to social dumping. The relative labour costs not only depend on direct and indirect wage costs, but also on other factors such as productivity, which in its turn depends on the means and techniques of production used, the employees' level of training and the general material and administrative infrastructure of the country concerned. Therefore the absolute difference in wage

\footnotetext{
$16 \quad$ Case C-382/92, Commission v. United Kingdom, para. 15.

17 D. Ashiagbor, 'Embedding Trade Liberalization in Social Policy: Lessons from the European Union?' o.c., 384-387; C. Barnard, EU Employment Law, o.c., 36-38 and Streeck, W. 'Neo-voluntarism: A New Social Policy Regime', ELJournal 1995, 31 et seq.

18 See, for an in-depth analysis of this issue: A. Saydé, 'One Law, Two Competitions: An Enquiry into the Contradictions of Free Movement Law', in C. Barnard and O. Odudu (eds.), Cambridge Yearbook of Legal Studies, Vol. 13, 2010-2011, Oxford, Hart, 2012, 391-399.
} 
costs as such is not a source of unfair competition or social dumping. ${ }^{19}$ A recent study shows that, from the perspective of the relative labour costs, labour costs transposed into purchasing power and in terms of productivity in the EU, Member States do not differ all that much. ${ }^{20}$ In addition, it is apparent that the differences in wages and employment protection between the Member States are no longer a matter of differences between the new Member States of Central and Eastern Europe and the socalled old Member States. In a number of new Member States in Central and Eastern Europe the pay level has increased more rapidly than the level of productivity over the past ten years. ${ }^{21}$ The 'old' Member States such as the United Kingdom, Ireland and Luxembourg are the ones which, generally speaking, have a competitive advantage because of their weaker employment protection and low amounts of taxes and social security contributions withheld. This explains why, in practice, delocalisation has not so much taken place between old and new Member States, but rather to these three Member States. ${ }^{22}$ In the past decade we have witnessed how undertakings have been using the existing differences in labour costs as an argument to move establishments within the internal market or to put pressure on the local level of pay and employment protection through collective bargaining. ${ }^{23}$ The undertakings clearly use the difference in labour costs between the Member States as a competitive element. In that sense the European internal market has created a kind of regulatory competition between the Member States which also leads to competition between the employees of the Member States concerned.

Still, it would be wrong to state that within the European internal market the labour costs in the various EU Member States are kept so artificially low as to cause unfair competition and social dumping. ${ }^{24}$ Moreover, from a political point of view it is not very likely that social achievements would be shoved aside just like that at the national level. ${ }^{25}$ The impact of the EU economic governance on the employment protection in the Member States is undoubtedly much bigger than the impact of the internal market rules on free movement as such.

This does not alter the fact that in certain branches of the economy, such as in the construction industry, transport industry and agriculture and horticulture wage competition between the employees of these countries can be felt. This is especially

19 M. Bernaciak, Social dumping: political catchphrase or threat to labour standards? ETUI Working paper 2012.06, Brussels, 2012, 17-18.

20 K. Maslauskaité, Social competition in the EU: Myths and realities, Notre Europe. Jacques Delors Institute, Studies and Report, No 97, June 2013, 59 p.

$21 \quad$ Ibidem, 25-27.

22 C. Barnard, 'Fifty Years of Avoiding Social Dumping', in M. Dougan and S. Curie (eds.), 50 Years of the European Treaties. Looking Back and Thinking Forward, Oxford, Hart, 2009, 317-319.

23 M. Bernaciak, o.c., 26-31 and C. Barnard, 'Fifty Years of Avoiding Social Dumping', o.c., 317-319.

24 K. Maslauskaité, Social competition in the EU: Myths and realities, o.c.

25 C. Barnard, 'Social Dumping and the race to the bottom: some lessons for the European Union from Delaware?'; ELRev. 2002, 70-74. 
the case when the pay and employment protection applicable in the Member State concerned is not respected and adequate control is lacking. In addition, there is the expansion of the so-called grey economy, such as bogus self-employment, subcontracting and temporary agency work which render control even more difficult. These practices appear to be a bigger cause of unfair competition and social dumping within the European internal market than the differences in pay and employment protection as such. ${ }^{26}$ Incidentally, the European internal market facilitates the development of these practices and the lack of control.

\section{THE TERRITORIAL APPLICATION OF LABOUR LAW IN CROSS-BORDER SITUATIONS}

\subsection{PRINCIPLE: FREE MOVEMENT OF WORKERS}

Social competition in terms of labour law does not only occur between Member States, but also within a Member State, more specifically when the job in question has a cross-border aspect. Yet this was not the intention, as the original Article 48 EEC (now Article $45 \mathrm{TFEU}$ ) stated very clearly that the free movement of workers within the Union entails the abolition of any discrimination on grounds of nationality between the workers of the Member States as regards employment, pay and other working conditions.

This principle means that migrating workers are entitled to the same pay and working conditions in the Member State where they work as those applicable to that Member State's own citizens. This prohibition of discrimination on grounds of nationality was also explicitly included in Article 7 Regulation 1612/68 ${ }^{27}$ (now replaced by Article 7 Regulation 492/201128) which for the application of this prohibition refers to the 'territory of ... Member States'. Article 7(4) of these Regulations also declares any provision of collective or individual employment contracts that is in conflict with this territorially applicable prohibition of discrimination on grounds of nationality legally null and void.

This requirement of equal treatment as regards pay and working conditions with the workers in the State of employment was not only inspired by concern about the social protection of migrant workers, but also by the wish to protect the Member States' own workers against workers from other Member States who might be willing to work for lower social conditions. The Court of Justice for its part has linked this

\footnotetext{
26 M. Bernaciak, o.c., 25-26.

27 Regulation (EEC) 1612/68 of the Council of 25 October 1968 on freedom of movement within the Community, OJ L 1968/257 (hereinafter referred to as 'Regulation 1612/68').

28 Regulation (EU) 492/2011 of the European Parliament and of the Council of 5 April 2011 on freedom of movement for workers within the Union, OJ L 2011/141, 1 (hereinafter referred to as 'Regulation 492/2011').
} 
requirement of equal treatment with the workers of the State of employment to Article 117 EEC (now Article 152 TFEU) in which the Member States recognise the necessity to promote the workers' standard of living and working conditions. The CJ stated expressly that the absolute nature of the prohibition of discrimination on grounds of nationality must guarantee the nationals of the State of employment that they will not be harmed by any offer to, or acceptance by, nationals of other Member States of less favourable working conditions than those valid in the national legislation of the State of employment. ${ }^{29}$

However, the Court of Justice decided that a posted employee of a crossborder service provider is not a worker within the meaning of Article 39 EC (now Article 45 TFEU) and Regulation 1612/68 (now Regulation 492/1011). ${ }^{30}$ The fact that these workers are excluded from the application of the Treaty provision on the free movement of workers has fundamental legal consequences. The question as to which employment protection scheme these workers can take recourse should, for the Court, be answered on the basis of the principles underlying the free movement of services, more specifically the right of these employees' employer to provide his services in another Member State without distinction in terms of nationality and without any other obstacles. In this legal context the application of the labour legislation of the host country has been regarded as an obstacle to the free movement of services by the employer concerned. In principle, he should have the right to continue to apply the labour law of the country of origin to his employees. In that case the possible application of the employment protection of the host State, should, since it can be an obstacle to the free movement of services, be justified for reasons of public interest and be proportional to this purpose (the so-called rule of reason). ${ }^{31}$ With this, the application of Regulation 1612/68 (now Regulation 492/1002) and of the prohibition of discrimination on grounds of nationality with regard to the pay and working conditions of Article 7 of these Regulations was rendered inoperative. ${ }^{32}$

29 Case 167/73, Commission v. France, para 45. See also Evju, 'Revisiting the Posted Workers Directive: Conflict of Laws and Laws in Contrast', in C. Barnard and O. Odudu (eds.) The Cambridge Yearbook of European Legal Studies, Vol. 12, 2009-2010, 153; and M. Houwerzijl, 'Towards a more effective Posting Directive', in R. Blanpain (ed.), Freedom of Services in the European Union, Bulletin of Comparative Labour Relations, The Hague, Deventer, 2006, 181.

30 Cases C-49/98 et seq., Finalarte, paras. 22-23.

31 See, inter alia, Case C-43/93, Vander Elst, para. 14 et seq.; Case C-272/94, Guiot, para. 10 et seq.; Cases C-369/06 and C-374/96, Arblade and Leloup, para 33 et seq.; Cases C-49/98 et seq., Finalarte, para. 28 et seq.; Case C-165/98, Mazzoleni, para. 22 et seq.; Case C-164/99, Portugaia, para. 16 et seq.; Case C-60/03, Wolff \& Müller, para. 31 et seq.; Case C-346/06, Rüffert, para. 37 and Case C-319/06, Commission v. Luxembourg, paras. 42-43. See, further, on this case law, under 4.3.1.

32 For a previous detailed analysis of this issue, see H. Verschueren, 'Cross-Border Workers in the European Internal Market: Trojan Horses for Member States' Labour and Social Security Law?' International Journal of Comparative Labour Law and Industrial Relations, 2008, 171-177. 


\subsection{THE TERRITORIAL APPLICATION OF LABOUR LAW AND PRIVATE INTERNATIONAL LAW}

The application of the principle of the prohibition of discrimination on grounds of nationality in Article 45 TFEU and in Article 7 of Regulation 492/2011 does not, however, always guarantee cross-border workers the application of the labour legislation of the country where they work at a certain moment. In principle, the rules of private international law (PIL) remain fully applicable and on the basis of these rules it is possible that the labour legislation of another country is applicable. These rules were laid down in the Rome I Convention of 19 June 1980 (Rome I Convention). ${ }^{33}$ At the end of 2009 this instrument was replaced by Rome I Regulation. ${ }^{34}$

The basis of these PIL instruments is the freedom of choice of the parties (Article 3 Rome I Convention and Article 3 Rome I Regulation). So, in principle, the parties of an employment contract have the freedom to depart from the territorial application of the labour law of the country where the activities are carried out. Still, this freedom of choice is limited. For employment contracts Articles 6 and 7 Rome I Convention and Articles 8 and 9 Rome I Regulation contain specific rules with regard to the determination of the law applicable to individual employment contracts, both in situations in which the parties have made a choice of law and in situations where no choice of law has been made. In the absence of a choice of law the principle is that the employment contract is subject to the law of the country where the employee usually carries out his job (or from where he usually carries out his job), ${ }^{35}$ even when he is temporarily employed in another country. ${ }^{36}$ When, as a rule, this employee does not carry out his job in the same country, the law of the country where the employer's establishment is situated is applicable. However, these arrangements are put aside if the circumstances as a whole show that the employment contract is linked more closely with another country, in which case the law of that other country applies. ${ }^{37}$ The law determined in the absence of a choice of law is sometimes referred to as 'objective applicable law'.

However, even if a choice of law has been made the employee may not lose the protection he enjoys on the basis of the mandatory provisions of the 'objective applicable law' (Article 6(1), Rome I Convention and Article 8(1), Rome I Regulation).

33 Rome Convention of 19 June 1980 on the law applicable to contractual obligations, OJ L 1980/266, 1 (hereinafter referred to as 'Rome I Convention').

34 Regulation (EC) 593/2008 of the European Parliament and of the Council of 17 June 2008 on the law applicable to contractual obligations (Rome I), OJ L 2008/177, 1 (hereinafter referred to as 'Rome I Regulation'). This Regulation applies to employment contracts concluded after 17 December 2009.

35 Specifically referred to in Article 8 (2), Rome I Regulation. This was confirmed by Case C-29/10, Koelzsch.

36 Recital 36 to the Rome I Regulation states in this regard: 'As regards individual employment contracts, work carried out in another country should be regarded as temporary if the employee is expected to resume working in the country of origin after carrying out his tasks abroad.'

37 See, in this respect also, Case C-384/10, Voogsgeerd and Case C-64/12, Schlecker. 
Moreover, pursuant to Article 7(1), Rome I Convention or Article 9 Rome I Regulation it is also possible to apply the 'overriding mandatory provisions' of the law of another country. These could, for instance, be invoked if the employee is temporarily employed in such a different country, as, for instance, in the case of posting. But the case law was, and is, not very clear as regards the question as to which 'overriding mandatory provisions' can be applied to posted workers.

So the application of these PIL rules, as harmonised at EU level, can have as a result that work carried out on the territory of a certain Member State is not, or only to a limited extent, subject to the labour law of that country. Indeed, according to these rules a posted employee continues to be subject to the labour legislation of the habitual place of work because he does not 'habitually' work on the territory of the country in which he is temporarily posted.

\subsection{THE TERRITORIAL APPLICATION OF LABOUR LAW UNDER PRESSURE AS A RESULT OF THE FREE MOVEMENT OF SERVICES}

\subsubsection{Free movement of services and the territorial application of labour law}

However, the strict application of these PIL rules has been nuanced by the case law of the Court of Justice and later by the European legislature. Indeed, the Court of Justice did not rule out that posted employees could be made subject to a number of provisions of the labour law of the Member State in which they had been posted, insofar as there is a balance between the right to free movement of services as exercised by the employers concerned and the employment protection of the employees concerned. ${ }^{38}$

In Rush Portuguesa the Court expressly stated that Union law does not prevent Member States from applying their legislation or collective labour agreements between the social partners for all those who - even temporarily - are employed on their territory, irrespective of their employer's country of establishment. ${ }^{39}$

The principles of the Rush Portuguesa judgment were once again confirmed by the Court in Vander Elst. ${ }^{40}$ Still, in this judgment the Court stressed other points than in Rush Portuguesa. In Vander Elst the Court restricts itself to the national rules of public policy, such as provisions on minimum wages and starts from the idea that the application of the labour law of the country of origin - in this case Belgium - should be sufficient to exclude 'any substantial risk of workers being exploited or of competition between undertakings being distorted' (paras. 23 and 25). In later judgments the Court stated that the application of the law of the receiving country is only allowed in the

\footnotetext{
38 See, inter alia, Case C-113/89, Rush Portuguesa; Case C-43/93, Vander Elst; Case C-272/94, Guiot; Cases C-369/96 and C-376/96, Arblade and Leloup; Case C-165/98, Mazzoleni; Cases C-49/98 et seq., Finalarte and Case C-164/99, Portugaia.

39 Case C-113/89, Rush Portuguesa, para 18.

40

Case C-43/93, Vander Elst.
} 
event that the protection offered by these provisions is not offered by identical or essentially comparable obligations to which the undertaking is already held in the Member State where it is established. ${ }^{41}$

\subsubsection{The Posting of Workers Directive}

\subsubsection{Objectives and content}

The basic principles of this case law are also at the basis of the so-called Posting of Workers Directive 96/71 (PWD). ${ }^{42}$ This is in the first place apparent from the legal basis which was used for this Directive, and which is part of the Free Movement of Services Chapter in the Treaties. There is no reference whatsoever to the Treaty provisions with regard to the free movement of workers. Its first intention is to facilitate the free movement of services by matching the Member States' legislation on the labour law applicable to posted workers.

Its provisions show that Directive 96/71 is an instrument of coordination and not of harmonisation. This is explicitly confirmed by Recital 13 and in the case law of the Court of Justice. ${ }^{43}$ In no way does this instrument harmonise elements of the Member States' labour law.

Therefore this Directive can be regarded as a PIL instrument in the sense that is a particularisation of Article 7 Rome I Convention and Article 9 Rome I Regulation on the basis of which effect may be given to mandatory rules of the law of a country other than that whose law is applicable pursuant to Article 6 Rome I Convention and Article 8 Rome I Regulation. ${ }^{4}$ This could concern the law of the country on whose territory the worker is temporarily employed. So, the PWD does not change the law applicable to the labour relations pursuant to the above described rules of private

41 See, inter alia, Case C-445/03, Commission v. Luxembourg, para. 29; Case C-244/04, Commission v. Germany, para. 44 and Case C-168/04, Commission v. Austria, para 47.

42 Directive 96/71/EC of the European Parliament and of the Council of 16 December 1996 concerning the posting of workers in the framework of the provision of services, OJ L 1997/18, 1 (hereinafter referred to as 'PWD').

43 Case C-490/04, Commission v. Germany, paras. 17-19; Case C-341/05, Laval, paras. 60, 68 and 108; and Case C-522/12, Isbir, para. 35.

44 See also Recital 10 of Directive 96/71. Legal doctrine also generally refers to this Directive as a special rule within the meaning of Art. 7 Rome I Convention: S. Evju, 'Revisiting the Posted Workers Directive: Conflict of Laws and Laws in Contrast', o.c., 168-169; S. Guibboni, 'Social rights and Market Freedoms in the European Constitution: A Re-Appraisal', ELLJ 2010, 174; M. Houwerzijl, 'Towards a more effective Posting Directive', o.c., 184; and M. Fallon, 'Le détachement européen des travailleurs à la croisée de deux logiques conflictualistes', Rev. criv. DIP 2008, 802803. In the same vein, see the opinion of 18 September 2014 of Advocate General WAHL in case C-396/13, Sähköalojen ammattiliitto ry, paras. 47-57. See, more specifically, on the link between the PWD and the rules of PIL: A. van Hoek and M. Houwerzijl, 'Posting' and 'Posted Workers': The Need for Clear Definitions of Two Key Concepts of the Posting of Workers Directive', in C. Barnard and M.W. Gehring (eds.), The Cambridge Yearbook of European Legal Studies, Vol. 14, 2011-2012, Oxford, Hart, 2012, 437-443. 
international law, but establishes, in line with what is made possible by Article 7 Rome I Convention and Article 9 Rome I Regulation, which 'special' mandatory provisions of the labour law of the country of temporary employment apply, 'whatever the law applicable to the employment relationship". ${ }^{4}$ The PWD clarifies the possibility offered by PIL. It actually concerns a harmonisation of what the host State could consider to be 'special mandatory law' with regard to posted workers. In that sense Directive 96/71 offers the worker additional protection and strengthens the territorial scope of the labour law of the host State and the territorial application of the Member States' labour law. ${ }^{46}$

The Posted Workers Directive does not impose the application of all of the labour law provisions of the receiving State, but only of those provisions that constitute the core of mandatory provisions for minimum protection (the so-called hard core), more specifically (see Article 3(1)): maximum work periods and minimum rest periods; minimum number of paid annual holidays; minimum wages; conditions for the posting of employees, in particular by temporary employment agencies; health, safety and hygiene in the workplace; protective measures for special groups of employees (pregnant women, youngsters); provisions regarding equal treatment and nondiscrimination. The Directive has laid down this hard core as part of Union law and as a result the Member States are obliged to apply this hard core to posted workers. ${ }^{47}$

However, the Directive does limit the method the Member States can use for this. Only the following provisions qualify: legal and administrative provisions and/ or collective agreements or arbitration awards which have been declared universally applicable and in so far as these concern the activities intended in the annex. ${ }^{48}$ As for the collective agreements, Article 3(8) specifies which labour agreements or arbitration awards qualify, especially regarding the general validity of these norms for all undertakings that belong to the occupational group or industry concerned and are subject to the territorial scope of these agreements or decisions. Minimum wages that have not been laid down through these legal instruments are not minimum wages within the meaning of this Directive and therefore cannot be imposed by the Member States in the case of cross-border provision of services. The Court reached this very strict interpretation in Laval and Rüffert. ${ }^{49}$

The objectives of this coordination instrument are multiple, if not paradoxical. ${ }^{50}$ Its first aim is the promotion of the free movement of services by regulating which

\footnotetext{
45 See, expressly, this parenthesis in Article 3(1), first paragraph PWD.

46 S. Deakin, 'Regulatory Competition after Laval', o.c., 594.

47 Case C-490/04, Commission v. Germany, para. 17.

48 This concerns 13 activities, especially in construction, demolition and maintenance. On the basis of Article 3(10) the Member States can also apply collective agreements or arbitration awards to other activities.

49 Case C-341/05, Laval, paras. 70 and 71 and Case C-346/06, Rüffert, para. 31.

50 See for a recent account of this paradox, the opinion of 18 September 2014 of Advocate-General WAHL in case C-396/13, Sähköalojen ammattiliitto ry, paras. 26-32.
} 
Member State's labour law is applicable to the employees of the cross-border provider of services. But simultaneously, it aims at being an instrument to prevent social dumping and unfair competition. It represents a compromise between the competing interests of the Member States sending out foreign workers and those receiving them. ${ }^{51}$ Both of these objectives have been explicitly recognised by the Court of Justice. ${ }^{52}$ Yet, the case law of the Court of Justice also makes it clear that the receiving States' room to manoeuvre with a view to applying additional elements of their labour law to posted workers is very limited. As regards the provision in Article 3(7) PWD, the Court expressly stated in Laval that this cannot be interpreted to the effect that it allows the receiving Member State to make the performance of services dependent on compliance with terms and conditions of employment that exceed the mandatory provisions for minimum protection. The level of protection that the receiving Member State has to guarantee for workers posted on its territory is in principle limited to the 'hard core' provisions, unless pursuant to the law or collective labour agreements valid in the Member State of origin the working conditions and circumstances are already more favourable for these workers. ${ }^{53}$

On the other hand, Article 3(10) PWD does allow the Member States to extend that hard core 'on matters other than those (...) in the case of public policy provisions'. This refers to terms and conditions of employment that are not part of the list included in Article 3(1). However, in its judgment Commission v. Luxembourg, the Court of Justice gave a strict interpretation of these provisions. According to the Court the exception of public policy is a derogation of the fundamental principle of the free provision of services, which has to be conceived strictly and whose scope cannot be determined unilaterally by the Member States. For the Court public policy can only be invoked when there is a real and sufficiently serious threat to a fundamental interest of society. ${ }^{54}$ This interpretation of the concept of 'public policy' actually means a serious restriction of the Member States' ability to impose the application of other elements of their labour law to their posted employees on the basis of this provision.

In Rüffert the Court furthermore explained that the Member States, apart from their public policy claim, do not have the possibility to guarantee the avoidance of social dumping and to ensure fair competition in any other way than through the strict interpretation of the possibilities offered by the Directive. In Rüffert the Court expressly states that imposing minimum wages cannot be regarded as a measure to protect employees which could possibly justify an obstacle to the free provision of

\footnotetext{
$51 \quad$ Ibidem, para. 30.

52 Case C-60/03, Wolff \& Müller, para. 42; Case C-244/04, Commission v. Germany, para. 61; and Case C-341/05, Laval, paras. 74-75. See also the fifth Recital to the PWD.

53 Case C-341/05, Laval, paras. 80-81 and Case C-346/06, Rüffert, paras. 33-34. The Court also provides for the possibility that undertakings established in other Member States voluntarily join in a more favourable collective agreement in the receiving Member States, inter alia, in the context of a commitment to their own posted workers.

54 Case C-319/06, Commission v. Luxembourg, paras. 29, 30, 49 and 50.
} 
services when these wages only apply to the performance of government assignments and not to private assignments in the same industry and region. ${ }^{55}$ Therefore the Member States can only force the employer of the posted employee to pay the minimum wages valid in the receiving Member State as laid down in the PWD. Otherwise, there would be a conflict with Article 56 TFEU, since the legislation of the host State imposes 'on service providers established in another Member State where minimum rates of pay are lower an additional economic burden that may prohibit, impede or render less attractive the provision of their services in the host Member State. ${ }^{56}$

In the Court's opinion the strict application of the PWD and the possibilities it offers is sufficient to avoid social dumping. Thus this Directive has actually become the maximum protection which can be invoked by posted workers. ${ }^{57}$ The CJ very recently confirmed this position in a judgment of 19 September $2014 .{ }^{58}$ On the basis of his analysis of this case law, Advocate-General WAHL opines that the Court has seemingly shifted its focus from the protection of the domestic labour market to the freedom to provide services. ${ }^{59}$ The CJ has tried to save both objectives of the PWD. First, as an instrument of employment protection, it contributes to creating a level playing field of protection of all workers active on the territory of the host State. But, second, as an internal market instrument it allows employers to make use of the competitive advantages of the differences in wages and employment protection between Member States.

\subsubsection{The Member States' ability to organise efficient control of compliance} with the applicable employment provisions

As Union law on the determination of the applicable labour law in the case of posting deviates from the territorial application of the labour law of the Member State where the employer concerned temporarily provides services with his own employees, efficient control of the application of these rules and of the protection offered to the employees by the PWD is of crucial importance. However, after over 15 years of application of this Directive it has now become clear that in practice there are a lot of problems as regards the legal position of posted workers. These include posting through letter-box companies, false declarations of posting, long-term postings, repeated replacements of posted workers, bogus self-employed persons, ${ }^{60}$ non-payment of social security contributions in the sending country, non-payment of the minimum wages of the

\footnotetext{
55 Case C-346/06, Rüffert, paras. 38-40.

56 Case C-346/06, Rüffert, para. 37.

57 C. Kilpatrick, 'Laval's regulatory conundrum: collective standard-setting and the Court's new approach to posted workers', European Law Review 2009, 844-865.

58 Case C-549/13, Bundesdruckerei, para. 30.

59 Opinion in C-396/13, Sähköalojen ammattilitto ry, paras. 32 et seq.

60 Compare: F. Muller, 'Cross-border mobility of 'bogus' self-employed workers: a lack of legal framework coupled with protection of economic rights', ELLJ 2014, 306-321.
} 
receiving country, non-observance of the rest and work periods and rules on wellbeing at work, failure to compensate the expenses of posting such as accommodation expenses, bad housing of the employees concerned, pyramids of sub-contractors that make control difficult, U-turn constructions through brass plate firms, etc. ${ }^{61}$

As regards these control measures Article 5 PWD expressly states that the Member States have to take appropriate measures when the provisions of this Directive are not complied with. In its case law the CJ has always emphasised that the Member State whose pay and working conditions apply can enforce the application of these rules with appropriate means. ${ }^{62}$ The CJ accepted, for instance, as compatible with EU law a system of several liability of the main contractor to pay the minimum wages to his subcontractors' employees. ${ }^{63}$ Registration prior to the employment of posted workers was also considered by the Court to be an acceptable control measure. ${ }^{64}$ Furthermore, the Court considered the request that a translation of certain documents in the language of the receiving Member State be kept in the workplace to be justified. ${ }^{65}$ And recently, the CJ also accepted the Belgian legislation under which the recipient of services performed by workers posted by a service provider established in another Member State is required to present the data identifying those workers to the competent authorities, before those workers begin to work. ${ }^{66}$

However, control measures in the receiving State can run into legal limits. According to the Court these measures are also subject to a rule of reason test. ${ }^{67} \mathrm{~A}$ number of national control measures failed this test, such as the obligation to draft and retain social documents in accordance with the legislation of the host State while

61 For recent research on these phenomena, see A. van Hoek and M. Houwerzijl, Comparative study on the legal aspects of the posting of workers in the framework of the provision of services in het European Union, University of Nijmegen, 2011, 363 p.; A. van Hoek and M. Houwerzijl, Complementary study on the legal aspects of the posting of workers in the framework of the provision of services in het European Union, University of Amsterdam, 2011, 423 p., (both these studies to be consulted on http://ec.europa.eu/social/main.jsp?catId=471\&langId=en); N. Clark, Regulation and Enforcement of Posted Workers Employment (POSTER), Final report, 2012, to be consulted on www. workinglives.org/research-themes/migrant-workers/posted-workers.cfm. See also N. Countouris and S. Engblom, 'Civilising the European Posted Workers Directive', in M. Freeland and J. Prassl (eds.), Viking, Lawal en Beyond, Oxford, Hart, 2014, 282-285; and A. van Hoek and M. Houwerzijl, "Posting' and 'Posted Workers': The Need for Clear Definitions of Two Key Concepts of the Posting of Workers Directive', o.c., 421-437.

62 Case C- 62-63/81, Seco, para. 14; Case C-113/89, Rush Portuguesa, para. 18; Cases C-369/06 and C-374/96, Arblade en Leloup, paras. 38, 61-63 and 74; Case C-168/04, Commission v. Austria, para. 47; and Case C-244/04, Commission v. Germany, para 36.

63 Case C-60/03, Wolff \& Müller.

64 This possibility was expressly recognised by the Court of Justice in Case C-244/04, Commission v. Germany, para 41.

65 Case C-490/04, Commission v. Germany, paras. 71-72.

66 Case C-315/13, De Clercq (judgment of 3 December 2014).

67 See, specifically, Cases C-369/06 and C-374/96, Arblade and Leloup, paras, 36. See also Case C-60/03, Wolff \& Müller, paras, 28-30; Case C-445/03, Commission v. Luxembourg, para, 40; and Case C-244/04, Commission v. Germany, para. 36. 
the service provider concerned already had to keep similar records pursuant to the legislation of the Member State where he was established. ${ }^{68}$ The Court also criticised the fact that prior to the posting permission had to be requested for the employment and entry of posted workers who are not nationals of a Member State. ${ }^{69}$ More recently the Court ruled that, with regard to the self-employed, the information requested by Belgium prior to the beginning of the activities, was too detailed. ${ }^{70}$ The Court, however, expressly confirmed in this judgment that the objective of combating social fraud and the prevention of abuse, notably false self-employment and moonlighting, can be objectives to justify possible restrictions of the free movement of services. In this respect the Court also referred to the objective to protect the financial balance of the social security schemes, the objective to prevent unfair competition and social dumping and the objective to protect employees and self-employed persons. ${ }^{71}$

As a result of this restrictive case law of the Court of Justice in the context of the increasing use, according to some misuse, the demand for more mandatory European rules on the enforcement of the provisions of the PWD has been increasing. In this context Directive 2014/67/EU was adopted on 15 May 2014. ${ }^{72}$ This new Enforcement Directive is intended to establish a general framework of measures and control mechanisms that should lead to a better and more uniform implementation, application and enforcement of the PWD in practice, among which measures to prevent and fight any misuse and skirting of the applicable rules. For instance, in this new Directive an indicative, non-exhaustive list of qualitative criteria has been included that are characteristic of both the temporary nature inherent to the concept of posting and of the existence of a real link between the employer and the Member State from where the posting takes place (Article 4). It is the intention to prevent all forms of misuse, for instance long-term postings, repeated replacements of posted workers or the use of socalled letter-box firms. If such misuses are identified, the PWD would not be applicable. However, this new Directive does not indicate which employment law would then be applicable to the workers concerned. This is presumably the law of the host State.

A crucial provision in the new Directive is Article 9 that outlines which control measures may be taken by the receiving Member State. It has been agreed that this list will not be limitative. But in exchange the European Commission was given the mandate to test all other measures the Member States could take against the

8 Cases C-369/06 and C-374/96, Arblade and Leloup.

69 Case C-168/04, Commission v. Austria and Case C-91/13, Essent Energie Products.

70 Case C-577/10, Commission v. Belgium, para. 55.

71 Case C-577/10, Commission v. Belgium, para. 45.

72 Directive 2014/67/EU of the European Parliament and of the Council of 15 May 2014 on the enforcement of Directive 96/71/EC concerning the posting of workers in the framework of the provision of services and amending Regulation (EU) No 1024/2012 on administrative cooperation through the Internal Market Information System ('the IMI Regulation'), OJ L 2014/159, 11 (hereinafter referred to as 'Enforcement Directive'). 
requirements set by the Court of Justice with regard to the prohibition of obstructing the free movement of services in a disproportionate way.

Article 12 contains another important provision, more specifically the several liability in the case of sub-contracting. The Member States can introduce forms of several liability of the direct main contractor. As for the construction industry, this is said to amount to an obligation. Furthermore, the Member States can also apply several liability to contracts of other intermediaries than the direct contracting parties.

We will have to wait and see whether this Enforcement Directive is an efficient instrument to counter the misuse in posting. Still, it is a fact that this Directive does not change the legal framework within which posting is possible, nor the employment protection for the posted workers. The regulatory competition within a Member State made possible by this continues to be maintained.

\subsection{THE POSTED WORKERS' POSITION AT THE CROSS-ROADS OF LEGAL RULES AND OF ECONOMIC INTERESTS}

From the previous analysis it follows that pursuant to Union law the posted workers' position in terms of labour law is situated at the intersection of applicable rules of law. In addition, it is also at the crossroads of the economic interests of the parties concerned, i.e. the Member States, the employees and the employers (both those making use of posting and those normally economically active in the receiving country).

As far as the rules of law are concerned this is a matter of the territorial application of labour law and the principle of equal treatment for all work carried out on the territory of a Member State on the one hand, and the 'country of origin principle' of free movement of services on the other. Both are guaranteed by Union law. The first principle does not only aim at protecting cross-border workers by giving them the right to the same treatment as the other workers in the State of employment, but also at protecting the latter against social competition by the migrant workers. The second principle aims at protecting the cross-border service providers against unjustified obstacles to the free movement of services that would be used if the country where the party concerned temporarily provides services were to try to apply its own rules of law to that party. It illustrates the 'trade-off between regulatory neutrality and regulatory competition [which] accounts for fundamental ambiguity of internal market law towards social dumping' ${ }^{73}$

The PWD and the strict interpretation by the CJ of the possibilities the receiving States have to grant supplementary protection to the posted employee, on top of the protection offered by this Directive, strike a legally precarious balance between those

\footnotetext{
73 A. Saydé, o.c., 408 and A. Saydé, Abuse of EU Law and the Regulation of the Internal Market, Oxford, Hart, 2014, 309-314.
} 
two principles. This precariousness is even reinforced by the critical attitude of the CJ with regard to the control measures used by the receiving Member States to assert the right application of the rules of law concerned. The recent discussion within the Council of Ministers about the Enforcement Directive proposed by the European Commission is a perfect illustration of this.

This discrepancy was especially striking in Vicoplus. ${ }^{74}$ In this case the Court of Justice held that workers posted by a temporary employment agency actually do enter the labour market of the Member State to which they are posted and therefore do fall within the transitional provisions on the free movement of workers in the Accession Treaties. The Court holds the view that these workers effectively enter the labour market of the host Member State because during the period of their posting the posted workers normally have a job within the user undertaking which would have otherwise have been carried out by workers of that undertaking. ${ }^{75}$

Yet the Court does not conclude that these workers are migrating workers within the meaning of Article 45 TFEU, for in that case they could invoke the right to equal treatment with the local workers. But the judgment does indicate that the posting is at the cross-roads of two elements of Union law on the internal market, notably the free movement of workers and the free movement of services. With regard to the employment protection of these workers the Court continues to give priority to the provisions on the free movement of services. ${ }^{76}$

At the level of the Council of Europe, too, there was criticism of the approach in the PWD and the case law of the Court of Justice. As a result of a collective complaint against Sweden the European Committee of Social Rights, in a decision of 3 July 2013, was very critical of the restrictions imposed by the PWD and the case law of the Court of Justice regarding the application of Swedish labour law to workers posted in Sweden. ${ }^{77}$ Formally, the complaint was against the Swedish legislation which had transposed the CJ's case law into national law, especially in the abovementioned cases Laval, Rüffert, and Commission v. Luxembourg. In the context of this contribution it is particularly important to highlight the Committee's view that the Swedish legislation is in conflict with Article 19(4) of the European Social Charter which orders the States not to treat foreign workers less favourably than their own workers as regards wages, working conditions and collective bargaining. The Committee does recognise that

$74 \quad$ Cases C-307/09 et seq., Vicoplus et al.

75 Cases C-307/09 et seq., Vicoplus et al, paras. 31-32.

76 The Court took the same ambiguous position in Cases C-611/10 and C-612/10, Hudzinski and Wawrzyniak. In this judgment the Court held the view that posted workers could invoke the Treaty provisions on the free movement of workers (Articles 45 to 48 TFEU) to receive social benefits (in this case family benefits) from the host State.

77 European Committee of Social Rights, Decision of 3 July 2013, complaint No 85/2012, Swedish Union Confederation (LO) and Swedish Confederation of Professional Employees (TCO) v. Sweden. See, on the decision also, M. Rocca, 'A clash of kings. The European Committee of Social Rights on the 'Lex Laval' ... and on the EU framework for the posting of workers', European Journal of Social Law 2014, 217-232. 
posted workers find themselves in a special situation and that they differ from migrant workers who go and work for an employer in another Member State on their own initiative. But for the Committee, posted workers are workers who reside and work legally on the territory of the host country. Therefore they fall within the application of the prohibition of discrimination of Article 19(4) of the Social Charter. So, for the Committee, during their stay and employment they have the right to equal treatment with the host country's own workers as regards pay and other employment terms. ${ }^{78}$ Furthermore, the Committee holds the view that the restrictions on collective actions, which, pursuant to the Swedish legislation, are only allowed if their purpose is to guarantee a minimum protection for the posted workers, and not if their purpose is to effectively obtain the same employment protection as the country's own workers, are in conflict with Article 19(4)(b) and Article 6 (the right to collective bargaining and collective action) of the European Social Charter.

In this decision the Committee makes no attempt to disguise its criticism of the legal order of the EU. It does recognise that facilitating cross-border service provision by the posting employer is an important part of the economic freedoms of the EU, which are held in high esteem by the Committee. But from the perspective of the values, principles and fundamental rights laid down in the European Social Charter, these market freedoms cannot a priori be more valuable than these fundamental rights. For the Committee, Union law must be interpreted and applied to the effect that, among other things, it must recognise the fundamental right to equal treatment and the fundamental right of trade unions to strive for the protection and improvement of the living and working conditions of the employees. ${ }^{79}$

Besides, posting is not only situated at the cross-roads of the free movement of workers and the right to equal treatment on the one hand and the free movement of services of the employer on the other; legally it is also situated at the cross-roads of Union law on the free movement of workers and Union law concerning the rules applicable to an employment contract (PIL). Pursuant to the rules in the Rome I Convention and Rome I Regulation, the law of the country of habitual employment applies to the employment contract, and this country is not supposed to change in the case of temporary employment in another country, among which are posting activities. ${ }^{80} \mathrm{But}$ the theoretical continuation of the application of the law of the country of habitual employment can be mitigated by the application of 'overriding mandatory provisions' or rules of 'public policy (ordre public)' of another country, in particular the country where a posted worker temporarily works. The source of inspiration of the PIL rules is

\footnotetext{
78 See paras. $134,136,140$ and 141 of the Decision.

79 See paras. 121 and 122 of the Decision.

80 Note that the 'country of habitual employment' in the PIL rules is not necessarily the same as the 'country of origin' of the employers within the meaning of EU internal market law. See, on this issue, A. van Hoek and M. Houwerzijl, "Posting' and 'Posted Workers': The Need for Clear Definitions of Two Key Concepts of the Posting of Workers Directive', o.c., 440-442.
} 
the protection of the weaker contracting party. ${ }^{81}$ In this respect, too, the PWD tried to find a balance. But although the applicable PIL rules give the receiving Member State a certain level of flexibility to apply parts of its employment protection, the Court of Justice in its case law on the PWD has seriously restricted this flexibility by stating that these Member States may not impose protection that exceeds the protection allowed by the PWD. Otherwise, there would be a conflict with EU internal market law.

From the fact that in its case law the Court interprets any abrogation of the country of origin principle very strictly it is clear that the Court implicitly gives priority to the interests of those that make use of the free movement of services. ${ }^{82}$ In so doing the Court has paved the way for the use of the competitive advantage offered by the possibility to carry out activities and provide services in a Member State under employment conditions which apply in another (read cheaper) Member State, with the exception of 'hard core' provisions listed in Article 3(1) PWD. This was even recognised by the European Commission in a recent document in which it states that 'posting workers allows companies to exploit their competitive advantages across borders' ${ }^{83}$

For some, the CJ's case law distorted the 'the delicate balance between competing objectives'. ${ }^{84}$ This case law is also said to run counter to what the authors of the Directive intended in 1996. They are said to have offered more room for manoeuvre to the receiving Member States through the provisions of Article 3(7) and (10) PWD. ${ }^{85}$ In any case, as a result, the regulatory competition regarding wage and employee protection between the Member States is being imported into the Member States themselves. ${ }^{86}$ Moreover, it overturns the principle of territorial application of the labour law of the Member States which was laid down in the EEC Treaty of 1957 in the instruments regarding the freedom of movement for workers, thus allowing the exploitation of the competitive advantage of companies established in Member States with low wage standards. ${ }^{87}$

81 See, in this vein, the use by the Court of Justice of the concept of 'favor laboratoris' in the application of the Rome I Convention in Case C-29/10, Koelzsch, para. 46.

See, in the same vein, C. Barnard, EU Employment Law, o.c., 226-227; S. Deakin, 'Regulatory Competition after Laval', o.c., 596-597; and S. Evju, 'Revisiting the Posted Workers Directive: Conflict of Laws and Laws in Contrast', o.c., 154. European Commission, Employment and Social Developments in Europe 2014, December 2014, 154. N. Countouris and S. Engblom, 'Civilising the European Posted Workers Directive', o.c., 282.

85 See M. Biagi, 'Fortune smiles on the Italian EU Presidency: talking half-seriously about the posted workers and parental leave directives', International Journal of Comparative Labour Law and Industrial Relations 1996, 104; M. Biagi, 'The 'posted workers' EU directive: from social dumping to social protectionism', in R. Blanpain (ed.), Labour Law and Industrial Relations. Bulletin of Comparative Labour Relations, The Hague, Kluwer, 1997, 177-178 and C. Kilpatrick, 'Internal market architecture and the accommodation of labour rights', in Ph. Syrpis (ed.), The Judiciary, the Legislature and the EU Internal Market, Cambridge, Cambridge University Press, 2012, 212-213 and 222-223.

S. Deakin, 'Regulatory Competition after Laval', o.c., 597; and N. Countouris and S. Engblom, 'Civilising the European Posted Workers Directive', o.c., 285-286.

87 S. Guibboni, 'European citizenship, labour law and social rights in times of crisis', European Journal of Social Law 2013, 203-204. 
The discussion on this regulatory competition within the territory of a Member State differs from the discussion on the regulatory competition between Member States. In the latter case this concerns goods and services produced in a Member State through cheap labour and subsequently exported to another Member State. Differences in standard of living and productivity could perhaps be a justification for this regulatory competition between Member States. Very recently the Court of Justice explicitly acknowledged that such regulatory competition is fully lawful in the context of the EU internal market. Member States to which goods or services produced in another Member State are exported, may not require that for the production of such goods or services the minimum wages fixed by their legislation should apply. The Court said that by imposing such a minimum wage linked to the cost of living in that Member State, but which bears no relation to the cost of living in the Member State in which the services are performed, the first Member State prevents subcontractors established in this Member State from deriving a competitive advantage from the differences between the respective rates of pay. For the Court, this goes beyond what is necessary to ensure that the objective of employee protection is attained. ${ }^{88}$ But this labour cost competition is far less justifiable if the wage competition occurs on the territory of one and the same Member State. In such a case one can hardly refer to a difference in labour costs justified by the difference in productivity and standard of living.

However, for others a Member State's wish to apply its own pay and employment protection to posted workers is inspired by protectionist motives, more specifically with a view to shielding its own undertakings from the competition within the European internal market said to be practiced by undertakings from other Member States. ${ }^{89}$ Furthermore, the application of the labour law of the host country to (potentially) posted workers from another Member State is not always considered to be in the interest of the posted workers themselves. It could also be the case that as a result of the application of the receiving state's labour law posting in that country is no longer profitable for the principal, with the effect that the secondment does not take place and the employee concerned runs the risk of losing his job. From this point of view wage competition is not regarded as unfair competition, but rather as a normal form of competition within the European internal market and the natural functioning of economic integration..$^{90}$ Even the PWD itself would have unacceptable protective characteristics, like being 'anti-competitive' and 'socially problematic', since it would protect local workers and would prevent workers from

88 Judgment of 18 September 2014 in Case C- 549/13, Bundesdruckerei, para. 34.

89 See, inter alia, R. Giesen, 'Posting: social protection of workers vs. fundamental freedoms?', CMLRev. 2003, 145-147 and 156-158; and D. Kukovec, 'Law and the Periphery', European Law Journal 2015, 406-428. See also the position taken by some parties in cases before the Court of Justice as reflected in the opinions of the Advocate-Generals in Case C-49/98 et seq., Finalarte, paras. 32-33; Case C-164/00, Portugaia, para. 15; and Case C-445/03, Commission v. Luxembourg, para. 51.

90 A. Saydé, Abuse of EU Law and the Regulation of the Internal Market, o.c., 314. 
other countries 'exploiting their lower wages as a competitive advantage in the internal market'. 91

\section{CONCLUSION}

The European internal market has unmistakably fuelled and strengthened the social competition between the workers of the Member States. The market integration has made it possible to export and offer, without restriction, goods and services produced in a Member State under the pay and working conditions valid there. The fact that the European Union only marginally harmonised the pay and working conditions applied in the Member States, has brought about a form of social competition that puts pressure on the employment protection in the Member States. Still, this competition as such does not appear to have led to a general downward spiral of employment protection. This has to do, among other things, with the differences in wage and employment protection related to the productivity and the standard of living in the Member States concerned. However, it does appear that some countries wanted to strengthen their competitive position through a restriction of the labour costs.

Furthermore, the internal market offers undertakings and employers the possibility to skirt around the labour legislation applicable in the Member State in which the employee actually works or to avoid its application altogether. This is especially the case for employees in cross-border employment. At the time of the establishment of the PWD in the $90 \mathrm{~s},{ }^{92}$ as well as very recently during the discussions in the Council of Ministers about the proposal for the Enforcement Directive, it was obvious that the traditional posting states, i.e. states with high unemployment figures and low levels of social protection, want to offer their undertakings as many opportunities as possible to use their competitive advantage on the European internal market through the cross-border posting of workers. The application of the labour law of the host country is only guaranteed to a limited extent as a result of which this Member State is faced with internal social competition.

More than ever before, the European Union with its internal market continues to struggle with the balance between, on the one hand, the freedoms of the internal market and the social protection the separate Member States have introduced on the other. From the above it is clear that the PWD and the case law of the Court of Justice try to reconcile, with disputable success, the prevention of unfair

$91 \quad$ F. Mustili and J. Pelkmans, Access Barriers to Services Markets. Mapping, tracing, understanding and measuring, CEPS Special Report No. 77/2013, Brussel, 2013, 51.

92 See, inter alia, M. Biagi, 'Fortune smiles on the Italian EU Presidency: talking half-seriously about the posted workers and parental leave directives', o.c., 97-109; and S. Evju, 'Revisiting the Posted Workers Directive: Conflict of Laws and Laws in Contrast', o.c., 165-174. 
competition on the one hand and the guarantee of effective competition on the other. ${ }^{93}$

For some authors, the answer to this is more European social regulation, inter alia, by using framework Directives that would still leave room to manoeuvre for the national legislature. Fundamental social rights should also play a bigger part in this debate. The fields in which labour law has been harmonised so far, are too limited and offer no solution to the social competition that has arisen within the European internal market. ${ }^{94}$ Others in their turn advocate a cutting back of the European internal market's influence on national labour law, and in particular on its territorial application. Labour law should, in the first place, remain the responsibility and competence of the Member States. ${ }^{95}$ In this context some propose to introduce in the PWD more possibilities for the host State to apply parts of its employment protection to posted workers, possibly via Article 3(7) PWD. ${ }^{96}$

As for the first option, it remains unclear to what extent more European labour legislation will lead to more and better employment protection. Indeed, recent discussions on the proposals of the Commission - for instance on the Enforcement Directive - have in any case shown that it is very difficult to achieve a political agreement at the European level in this respect. The risk that the European labour legislation which would come about in this context will, rather, lead to a decrease in the social protection of workers is not unreal.

As for the second option, the European institutions - among which is the Court of Justice - will have to be prepared to limit the influence of the so-called negative market integration on national social law by giving the Member States more room to manoeuvre with regard to the social legislation they want to apply.

93 M. Biagi, 'The 'posted workers' EU directive: from social dumping to social protectionism', o.c., 178-180; and M. Fallon, 'Le détachement européen des travailleurs à la croisée de deux logiques conflictualistes', o.c., 811-812 and 817-818.

94 See, inter alia, N. Countouris and S. Engblom, 'Civilising the European Posted Workers Directive', o.c., 290-292; S. Guibboni, 'European citizenship, labour law and social rights in times of crisis', European Journal of Social Law 2013, 194-216; and S. KLosse, 'Balancing Europe's Economic and Social Goals: Fighting a Losing Battle?’, European Journal of Social Law 2012, 176-192.

95 See, for instance, C. Joerges and F. Rödl, 'Informal Politics, Formalised Law and the 'Social Deficit' of European Integration: Reflections after the Judgments of the ECJ in Viking and Laval', E.L. Journal 2009, 1-19.

96 N. Countouris and S. Engblom, 'Civilising the European Posted Workers Directive', o.c., 287-288. 